\title{
1 Influence of earthworms on apolar lipid features in soils after one year of incubation
}

2

3

4

5

T.T. NGUYEN TU ${ }^{a, *}$, A. VIDAL ${ }^{b}$, K. QUENEA ${ }^{a}$, M. MENDEZ-MILLAN` \& S. DERENNE ${ }^{a}$

a Sorbonne Université, CNRS, EPHE, UMR 7619 Metis, F-75005, Paris, France

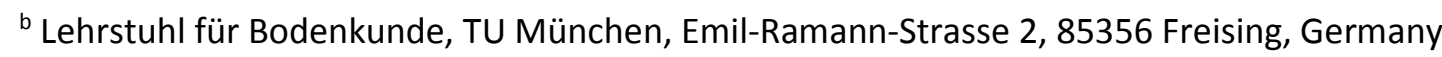

c IRD, Sorbonne Université, CNRS, MNHN, IPSL, LOCEAN, Bondy, France

* Corresponding author at: Sorbonne Université, Tour 56-66, 4 place Jussieu, 75252 Paris, France. E-mail address: Thanh-thuy.Nguyen_tu@upmc.fr (T.T. Nguyen Tu).

\section{Abstract}

Molecular and compound specific isotope compositions of apolar lipids were characterized in soil mesocosms incubated for one year with or without ${ }^{13} \mathrm{C}$-labelled plant residues and earthworms, in order to investigate, at the molecular scale, the effect of earthworms on the fate of organic matter (OM) in soils. Molecular and isotope composition of long chain alkanes in casts confirmed that earthworms preferentially ingest soil fractions rich in plant debris. Apolar lipid specific isotope composition allowed calculation of the proportion of carbon derived from the labelled residues $\left(\mathrm{C}_{\mathrm{lab}}\right)$.

Casts displayed higher $C_{\text {lab }}$ values than surrounding soil while soil without earthworm exhibited intermediate $\mathrm{C}_{\text {lab. }}$. The odd-over-even predominance (OEP) of alkanes suggested they are probably less degraded in casts than in the surrounding soil. Taken together, OEP and $\mathrm{C}_{\text {lab }}$ values suggested that besides high incorporation of plant residues, earthworms may also favor the preservation of plant apolar lipids in their casts. Additionally, chain length and isotope pattern of alkanes further suggested root lipids were probably less degraded than shoot lipids. High ${ }^{13} \mathrm{C}$-incorporation level for the bacterial biomarker hopene provided evidence for intense recycling of plant $\mathrm{OM}$ and suggested further contribution of bacterial necromass to soil OM.

\section{Keywords}


Earthworms, Organic matter, Lipids, ${ }^{13} \mathrm{C}$-labelling, Soil, Cast

\section{Introduction}

Soil organic matter (OM) is a key pool in the biogeochemical cycle of carbon. In the current global change context, precisely documenting the processes leading to OM decomposition and sequestration in soils is crucial as it may help in mitigating atmospheric $\mathrm{CO}_{2}$ levels (Jobbágy and Jackson 2000; Walthall et al. 2012). Soil ecosystem engineers, including earthworms, not only drive soil fertility and structure, but also OM decomposition (Bossuyt et al. 2005). They can enhance OM decomposition in soil but may also incorporate $\mathrm{OM}$ into their dejections (i.e. casts) that leads to its stabilization (Lavelle \& Martin 1992; Zangerlé et al. 2011; Vidal et al. 2017). Casts correspond to a mixture of minerals and $\mathrm{OM}$ at different degradation stages, which are fragmented and complexed with intestinal mucus thanks to transit in the earthworm gut (Lee 1985; Six et al. 2004). Bacterial activity promoted by earthworms in casts favors OM decomposition at the short-time scale (Brown et al. 2000; Vidal et al. 2016a). Conversely, at the month or year scale OM may be stabilized in drying casts (Brown et al. 2000; Martin 1991). Mechanisms behind OM decomposition in the presence of earthworms have often been often explored at the short-term, while factors controlling OM decomposition and stabilization at the larger time scale remain unclear. Indeed, recent studies have highlighted the lack of experiments at larger time scales ( $>200$ days) to depict the impact of earthworm of OM decomposition and carbon cycling (Lubbers et al. 2013; Angst et al. 2017). So far, the influence of earthworms on OM decomposition in soils was mainly studied at the bulk OM scale (Lavelle et al. 1998; Jégou et al. 2000; Six et al. 2004; Fonte et al. 2012; Stromberger et al. 2012; Fahey et al. 2013). However, soil OM corresponds to a complex mixture of molecules with diverse chemical structures and contrasted decomposition rate (Alexander 1981; Kelleher \& Simpson 2006). Few authors have investigated the chemical modifications induced by earthworms on soil and cast OM (Guggenberger et al. 1996; Filley et al. 2008; Crow et al. 2009; Hong et al. 2011; Frouz et al. 2015; Vidal et al. 2016a; Angst et al. 2017). These studies have notably pointed out: (i) the 
predominance of microbial- and lignin-derived compounds in casts when compared to soil (Guggenberger et al. 1996; Frouz et al. 2015;) and (ii) contrasted molecular evolution of shoot and root residues in casts (Vidal et al. 2016a). Enhanced OM physical protection was also identified as a major driving parameter for OM stabilization in casts (Angst et al. 2017). Incorporation and decomposition of $\mathrm{OM}$ is a dynamic process that involves both newly incorporated $\mathrm{OM}$ and indigenous OM. Differentiating these two pools of $\mathrm{OM}$ is also a main challenge in the study of carbon cycling in soils and casts. For this purpose, natural ${ }^{13} \mathrm{C}$-labelling is a powerful tool to monitor the fate and dynamics of OM in soils (Mariotti \& Balesdent 1990; Boutton 1996). Applied to the compound specific level, ${ }^{13} \mathrm{C}$-signatures in soils undergoing $C_{3} / C_{4}$ vegetation successions have shown that fatty lipids, sugars, as well as lignin, cutin and suberin monomers have contrasting turnover times (Wiesenberg et al. 2004; Bahri et al. 2006; Derrien et al. 2006; Mendez-Millan et al. 2010). The present work aims at studying the influence of earthworms on the dynamics of molecular constituents in soils. Lipids being of prime importance for soil fertility, water retention and aggregate stability (Jambu et al. 1978; Dinel \& Schnitzer 1990), the present study is focused on the fate of these hydrophobic compounds. Lipids further include biomarkers typical of the different sources of soil OM. This is notably the case of apolar lipids that generally contain long chain odd alkanes that are characteristics of plant-derived OM and hopanoids indicative of bacterial OM (Eglinton \& Hamilton, 1967; Peters et al. 2005). Apolar lipids may also exhibit a higher preservation potential than other lipidic molecules, especially compared with those comprising hydroxylated chemical functions such as fatty acids or cutins and suberins (Gonzalez-Vila, 1995; Schmidt et al. 2011). Besides, specific lipid ${ }^{13} \mathrm{C}$-measurements from natural or artificial labelling field experiments were proven valuable for evidencing complex decomposition dynamics in soil OM or revealing fungal contribution to its apolar lipid pool (Quénéa et al. 2006; Nguyen Tu et al. 2011; Mendez-Millan et al. 2014). The present study is based on a soil mesocosm experiment in which ${ }^{13} \mathrm{C}$-labelled plant residues were incubated in the presence or absence of earthworms. Shoot and root residues are the two key sources of plant OM in soils. They differ in decomposition rate and palatability, probably due to 
several factors including differences in chemical composition (Rasse et al. 2005). To selectively address this effect, root and shoot residues were added onto distinct mesocosms. The anecic earthworm Lumbricus terrestris was chosen for its ecological characteristics: it feeds on surface litter and transfers it along vertical burrows eventually depositing its organo-mineral casts on burrow walls and soil surface (Lee 1985; Jégou et al. 2001).

The experimental design allowed a first approach in investigating the influence of earthworms on (apolar) lipids after one year of incubation. The aims of the study were notably to (1) characterize apolar lipids in soil vs. casts and to (2) depict the contribution of shoot- and rootresidues to soil vs. casts apolar lipids, after one year of experiment. Distinguishing plant biomarkers from microbial biomarkers, this work further aims at characterizing the transfer of plant-derived carbon into microbial biomass in the presence or absence of earthworms.

\section{Material and methods}

Experimental setup

The samples used in the present study were collected from the mesocosm experiment described in Vidal et al. (2017). Briefly, six containers were filled with approximatively $75 \mathrm{~L}$ of a 4 mm-sieved loamy-sand soil, collected from permanent grassland in North of France (Oise, France). Six L. terrestris earthworms per container were deposited onto the surface of three of the containers. The amount of earthworms and plant residues deposited on the soil, as well as mesocosm size were designed so as to optimize earthworm survival in condition closest to reality (Vidal et al. 2017). Plants of Italian Ryegrass (Lolium multiflorum) were artificially labelled with ${ }^{13} \mathrm{C}$ at the Commissariat $\grave{a}$ I'Energie Atomique et aux Energies Alternatives (CEA) in Cadarache (France). After three months of growth under ${ }^{13} \mathrm{CO}_{2}$ enriched atmosphere, the mean $\delta^{13} \mathrm{C}$ values were $1324 \%$ o $( \pm 43)$ and $1632 \%$ o ( \pm 16$)$ for the roots and shoots, respectively (Vidal et al. 2017). Shoots and roots were separated, dried and subsequently mixed and homogenized during $40 \mathrm{~s}$. with a laboratory blender (Waring Commercial) to obtain few millimeter sticks. $250 \mathrm{~g}$ of plant residue per container were deposited on 
the soil surface of four containers: two with root residues and two with shoot residues. The last two containers represent the mesocosm controls without plant residue, including one with earthworms. The containers were then covered with coarse synthetic canvas to prevent earthworm escape and cross contamination by labelled residues. The mesocosms were placed in a greenhouse where soil humidity and temperature were maintained at $23 \%$ and $13^{\circ} \mathrm{C}$, respectively.

Weekly throughout the incubation, each container was vaporized with water (1 L/week) and seedlings or mosses developing in the mesocosms were manually eliminated. At the end of the experiment, no more residues were observed on the soil surface in the mesocosms containing earthworms, contrary to those without earthworm which exhibited remnant residues (ca. $30 \%$ of initial weight; Vidal et al. 2017). After one year, several samples representative of each mesocosm were collected, and pooled together to obtain a composite sample: (a) three soil cores $(2.5 \mathrm{~cm}$ diameter) were collected to a depth of $20 \mathrm{~cm}$ with an aluminum auger and (b) few grams of 3-4 earthworm cast fragments were randomly collected on the soil surface of earthworm containing mesocosms. Although mesocosm size did not allow replication, these composite samples provide an averaged estimation of the processes affecting plant lipids in the presence of earthworms. Samples were freeze-dried and ground prior to analyses. All in all, two undegraded plant residues, six soil and three cast samples were prepared for total lipid and lipid specific isotope analyses (Table 1). Bulk isotope compositions of the samples were reported previously (Vidal et al. 2017).

\section{Analyses}

Depending on the amount of organic carbon in the samples, between $2 \mathrm{~g}$ for plant samples and $20 \mathrm{~g}$ for soil and cast samples were used for lipid extraction with a solvent mixture of dichloromethane $\left(\mathrm{CH}_{2} \mathrm{Cl}_{2}\right)$ :methanol $\left(\mathrm{CH}_{3} \mathrm{OH}\right)(2: 1, \mathrm{v}: \mathrm{v})$ in an accelerated solvent extractor (ASE 100 Dionex) at $60^{\circ} \mathrm{C}$ and $10^{*} 10^{6} \mathrm{~Pa}$ for $10 \mathrm{~min}$. in two cycles. The combined extracts were concentrated by rotary evaporation, dried under $\mathrm{N}_{2}$ for weighing and further redissolved in $200 \mu \mathrm{L}$ of $\mathrm{CH}_{2} \mathrm{Cl}_{2}$. An aliquote of the total lipid extracts (TLE) was silylated with O-Bis(trimethylsilyl)trifluoroacetamide 
(BSTFA) (ca. $10 \%$ of the $\mathrm{CH}_{2} \mathrm{Cl}_{2}$ volume) prior to $\mathrm{GC}-\mathrm{MS}$ analyses for molecular identification. For lipid specific isotope analyses, the TLE was fractionated using column chromatography on alumina ( $1 \mathrm{~g}$ for $10 \mathrm{mg}$ of dried extract, Sigma-Aldrich 507C 150 mesh). Apolar lipids were recovered after elution with a solvent mixture (4 $\mathrm{mL}$ for $1 \mathrm{~g}$ of alumina) of heptane $\left(\mathrm{C}_{7} \mathrm{H}_{16}\right): \mathrm{CH}_{2} \mathrm{Cl}_{2}(99: 1, \mathrm{~V}: \mathrm{V})$. The apolar fraction was then concentrated by rotary evaporation and further dissolved in $3 \mathrm{~mL}$ of heptane. The TLE was analyzed with an Agilent 6890N gas chromatograph (GC) coupled with an Agilent $5973 \mathrm{~N}$ mass spectrometer (MS). The GC was fitted with a Restek RTX-5Sil-MS column ( $30 \mathrm{~m} \times 0.25$ $\mathrm{mm}$ i.d., $0.5 \mu \mathrm{m}$ film thickness) under constant helium flow of $1 \mathrm{~mL} / \mathrm{min}$. Samples were injected (1 $\mu \mathrm{L}$ ) in splitless mode with the injector temperature at $280^{\circ} \mathrm{C}$. GC operating conditions were as follows: initial temperature hold at $80^{\circ} \mathrm{C}$ for $30 \mathrm{~s}$, then increased from 80 to $100^{\circ} \mathrm{C}$ at $10^{\circ} \mathrm{C} / \mathrm{min}$ and from 100 to $320^{\circ} \mathrm{C}$ at $4^{\circ} \mathrm{C} / \mathrm{min}$ with a final isothermal hold at $320^{\circ} \mathrm{C}$ for $30 \mathrm{~min}$. The temperature of the transfer line to the $\mathrm{MS}$ was $320^{\circ} \mathrm{C}$ and the analytes were ionized by $70 \mathrm{eV}$ electron impact at $220^{\circ} \mathrm{C}$. The quadrupole was operated in scan mode $(35-700 \mathrm{Da})$ at $120^{\circ} \mathrm{C}$. Components were identified according to retention times and mass spectra fragmentation patterns. Compound-specific stable carbon isotope composition of apolar lipids were measured using an online continuous flow gas chromatograph Trace-GC-Ultra coupled with an Isotopic Ratio Mass Spectrometer Delta V Plus via a combustion furnace and a conflow IV interface from Thermo Fischer Scientific. The GC was equipped with a split/splitless injector, kept at $320^{\circ} \mathrm{C}$, and fitted with a $30 \mathrm{~m}$ fused silica capillary column (TR-5MS, $0.25 \mathrm{~mm}$ i. d., $0.25 \mu \mathrm{m}$ film thickness). The GC oven program started at $80^{\circ} \mathrm{C}$ during $2 \mathrm{~min}$., increased from 80 to $120^{\circ} \mathrm{C}$ at $10^{\circ} \mathrm{C} / \mathrm{min}$ and from $120^{\circ} \mathrm{C}$ to $320^{\circ} \mathrm{C}$ at $5^{\circ} \mathrm{C} / \mathrm{min}$. Finally the oven was kept at $320^{\circ} \mathrm{C}$ during $5 \mathrm{~min}$. Helium was used as carrier gas at constant flow of $2 \mathrm{~mL} / \mathrm{min}$. Accuracy and reproducibility of the GC-C-IRMS measurements were assessed with a standard mixture of $n$-alkanes $\left(n-C_{20}, n-C_{25}, n-C_{30}\right.$ and $n$ - $\left.C_{32}\right)$ of known isotopic composition (Schimmelmann, Indiana University). The standard mixture was injected three times at the beginning of each run and then once every three samples. Analytical standard deviation for each run was 
$<0.5 \%$ o $(n=6)$. The $\delta^{13} \mathrm{C}$ are expressed in \%o against the international standard VPDB (Vienna Pee Dee Belemnite).

\section{Results and discussion}

Molecular composition of TLE

Lipids account for less than $0.1 \mathrm{wt} \%$ of soil and cast samples while their content reaches $3.9 \mathrm{wt} \%$ and $17.2 \mathrm{wt} \%$ in root and shoot residues, respectively (Table 1). These lipid yields fall in the range of literature, although higher than that previously reported for L. multiflorum (Nguyen Tu et al. 2003, Göcke et al. 2013, Müller et al. 2013). Five major families of compounds are identified in both root and shoot residues: $n$-alkanes, $n$-alkanoic acids, $n$-alkanedioic acids, $n$-alkanols and sterols (Figure 1). These compounds are typical plant-derived lipids (van Bergen et al. 1998; Bull et al. 2000; Wiesenberg et al. 2010). Additionally, root TLE exhibits some lignin-derived compounds with $p$ coumaryl, guaiacyl and syringyl structures, as well as phenol. The main differences between root and shoot lipids stand in the presence of these aromatic compounds, as well as the higher relative abundance of long chain $n$-alkanoic acids $\left(>C_{20}\right)$ and sterols in root residues, while shoot residues presented a higher relative abundance of $C_{26} n$-alkanol (Fig.1).

The reference soil TLE (Soil-NE-control; Fig. 2.a) is dominated by $C_{12}$ to $C_{32} n$-alkanols maximizing at $\mathrm{C}_{26}$, with an even-over-odd carbon-number predominance. Long chain $n$-alkanols (> $\mathrm{C}_{20}$ ) typically derive from shoot waxes of terrestrial plants (van Bergen et al. 1998; Bull et al. 2000; Quénéa et al. 2004; Nierop et al. 2006; Quénéa et al. 2006) and are dominant constituents ( $\left.C_{26}\right)$ of shoot residue extract (Fig. 1). $n$-Alkanols can represent an important contribution to the OM stabilized in soils (Mueller et al. 2012) and are essential indicators of past plant types (Jansen et al. 2008). For example, Nierop et al. (2006) found $C_{26} n$-alkanol to be, by far, the dominant compound of lipid extracted from a pine forest soil. As pine biomass did not contain this $n$-alkanol, the authors suggested that the soil was probably covered by grass vegetation before pine trees were planted. $n$ Alkanoic acids also occur in substantial amounts in the reference soil, ranging from $C_{9}$ to $C_{32}$, with a 
strong even-over-odd carbon-number predominance and a maximum at $\mathrm{C}_{16}$, as frequently reported (Jandl et al. 2005; Wiesenberg et al. 2010). While $C_{16}$ and $C_{18} n$-alkanoic acids are ubiquitous in living organisms, $C_{20}-C_{26} n$-alkanoic acids are related to vegetal biomass in soils (Wiesenberg et al. 2004). The presence of trace amounts of iso- and anteiso-branched $C_{15} n$-alkanoic acids points to a bacterial contribution to soil lipids (Wannigama et al. 1981; Quénéa et al. 2012). $C_{16}$ to $C_{33} n$-alkanes, maximizing at $\mathrm{C}_{29}$ are identified in the soil, with a strong odd-over-even preference, as commonly observed (Lichtfouse et al. 1998; Bull et al. 2000; Wiesenberg et al. 2010). $C_{22}, C_{24}$ and $C_{26}$ $\omega$-hydroxyalkanoic acids are also identified in the soil and can originate from the in situ decomposition of cutin and suberin polymers (Quénéa et al. 2012). Taken together, the above data show that most compounds identified in the reference soil TLE derive from plant biomass and more specifically from grass plant. This is in agreement with the $>50$ year permanent pasture land use of the soil collected for the experiment (Vidal et al. 2016b).

The cast control extract is almost identical to the soil control extract (Fig. 2.b), with the exception of two isomers of a long chain unsaturated $n$-alkanoic acid: the arachidonic acid $\left(\mathrm{C}_{20: 4}\right)$ (Fig. 2). Arachidonic acid is a polyunsaturated $n$-alkanoic acid derived from eukaryotic organisms (Harwood and Russel 1984). Studies illustrating the link between this acid and earthworms are scarce. However, Schaefer et al. (2005) reported its significant increase in the presence of earthworms in an oil-contaminated soil. It was also identified in earthworm tissues (Albro et al. 1992) or in its gut content (Sampedro \& Whalen 2007). Thus, in the present study, the arachidonic acid identified in earthworm casts probably originates from (1) the earthworms themselves (i.e. their tissue or gut content) and/or (2) microorganisms stimulated by earthworms.

Differences observed in TLE of roots and shoots (Fig. 1) are no longer visible in cast and soil samples after 54 weeks of experiment (data not shown). Important differences are not necessarily observed in the lipid composition of soils underlying different plant species and organs (Nierop et al. 2006; Mueller et al. 2012). The distortion between plant and soil lipid composition could be explained by the strong legacy from other plant inputs in the soil (Nierop et al. 2006) and diverging 
affinity of lipids from different origins with soil mineral phase (Lutzow et al. 2006). Moreover, lipids might also be transformed in other compound classes over time. For example, $n$-alkanols might be oxidized into $n$-alkanoic acids during decomposition (Amblès et al. 1994). The reference soil and cast chromatograms highlighted a strong contribution from plant-derived compounds in the total lipid extracts. After 54 weeks of experiment, the legacy from past plant inputs seems to hide the potential differences in free lipids between the samples collected from mesocosms containing different residue type. Detailed molecular and isotopic investigations of apolar lipids were thus achieved to better document the fate of plant lipids in the presence or absence of earthworm.

\section{Apolar lipid distribution}

After one year of incubation, apolar lipids of all samples are dominated by $n$-alkanes that correspond to ca. $2 \%$ and $10 \%$ of TLE for plant residue and soil samples, respectively (Table 1 ). These bulk proportions are in agreement with those generally reported for plants and soils (Quénéa et al. 2004; Nguyen Tu et al. 2011; Srivastava \& Wiesenberg 2018). The distribution of apolar lipids is shown as histograms in Fig. 3. The reference soil without plant residue and without earthworm (soilNE-Control) shows a bimodal distribution of $\mathrm{C}_{16}-\mathrm{C}_{31}$ alkanes maximizing at $\mathrm{C}_{29}$ and submaximizing at $C_{20}$ (Fig. 3a). While long chain ( $>C_{23}$ ) homologues with odd carbon number predominance mainly correspond to plant contribution, shorter chain homologues with no carbon number predominance are generally attributed to mixed sources including soil microbes, such as bacteria and fungi (Kolattukudy et al. 1976; Jansen et al. 2006; Li et al. 2017). In addition, two pentacyclic triterpenes are identified at the end of the chromatogram (Online Resource 1): a hopene [hop-22(29)-ene] and a triterpenone [amyrenone]; they originate from bacteria and plants (Angiosperm), respectively (Ourisson et al. 1979; Otto et al. 2005; Peters et al. 2005). However, these two compounds are not detected in the apolar lipids of plant residues, which are exclusively composed of $n$-alkanes. The triterpenone (amyrenone) is also a by-product the degradation/oxidation of the corresponding triterpenol (amyrin). Its absence from initial plant residues is likely related to the undegraded stage 
of this plant material. The absence of bacterial biomarker from plant lipids is likely due to the absence of significant bacterial population on the plant residues. While shoot alkanes exhibit a unimodal distribution markedly dominated by the $\mathrm{C}_{29}$ homologue (Fig. $3 \mathrm{C}$ ), that of root is bimodal (maximum $\mathrm{C}_{27}$, submaximum $\mathrm{C}_{21}$; Fig. 3f). Difference in alkane distribution is a common pattern for roots and shoots from a given species (Jansen et al. 2006; Huang et al. 2011), including L. multiflorum (Gocke et al. 2013). Alkanes extracted from shoots of italian ryegrass were previously reported to maximize at $C_{31}$ (Gocke et al. 2013) or $C_{29}$ (Malossini et al. 1990), this difference being probably related to variations in developmental and/or environmental parameters (El-Otmani \& Coggins 1985; Gülz et al. 1991; Li et al. 2016).

Alkanes in the soils incubated in the presence of earthworms and/or plant residues (Fig. 3b, 3d, 3e, 3g and 3h) all exhibit a bimodal distribution as in the reference soil (Fig. 3a), although some differences can be noted in the relative abundance of the two modes. In contrast, cast $n$-alkanes are all dominated by odd chain long alkanes maximizing at $\mathrm{C}_{29}$ (Fig. 3b, 3e and 3h), even in the mesocosm without plant addition at the beginning of the experiment (cast-control). This distribution is typical of plant alkanes and consistent with the feeding habits of earthworms that preferentially ingest plant OM. The high abundance of the $C_{31}$ homologue in cast-root is unexpected given its low abundance in both initial soil and root residue. In the cast-control, the plant signature displays that earthworms select soil fractions rich in plant OM (Curry \& Schmidt, 2007; Vidal et al. 2016b). In the presence of plant residue (cast-root, cast-shoot), the plant signature of alkanes and the occurrence of triterpenone reflect the ingestion of both OM initially present in soil, and plant residues deposited on top of the mesocosms at the beginning of the experiment. In the same way, the hopene detected in the casts of these mesocosms (cast-root, cast-shoot) may correspond to both hopene initially present in the soil and that synthesized by earthworm gut microbiota. Indeed, previous analyses of faeces from millipedes grown exclusively in the presence of plant leaves revealed the presence of hopene while it was absent from the leaves, thus evidencing bacterial activity associated with gut transit (Rawlins et al. 2006). 
calculated for $n$-alkanes (Hoefs et al. 2002):

$\mathrm{OEP}=\left[n-\mathrm{C}_{27}+n-\mathrm{C}_{29}+n-\mathrm{C}_{31}+n-\mathrm{C}_{33}\right] /\left[n-\mathrm{C}_{26}+n-\mathrm{C}_{28}+n-\mathrm{C}_{30}+n-\mathrm{C}_{32}\right]$

Root and shoot residues exhibit OEP slightly higher than 5 (Table 1), as expected for undegraded plant material (Zech et al. 2009; Schaefer et al. 2016). In soils without earthworm, OEP is typical of topsoils $(<5$; Table 1$)$, the relatively low value for soil-NE-shoot (4.0) being likely related to a priming effect due to the deposition of nutrient-rich shoot residue at the beginning of the experiment. The priming effect consists of enhanced microbial degradation of native soil OM, induced by an input of fresh OM (Fontaine et al. 2004; Kuzyakov 2010). In the mesocosms with earthworms and with shoot residues or without plant residues, soils and casts display OEP $<4$ and $>5$, respectively (Table 1 ). According to literature (Buggle et al. 2010; Zech et al. 2009), these OEP suggest alkanes underwent some degradation in soils while they are less degraded in casts. This finding may be related to both higher incorporation and better preservation of plant residues in casts. Soil and cast from the mesocosm with root residues and earthworms exhibit very high OEP values (>>5) that are higher than the corresponding sample in shoot mesocosm (Table 1). These high OEP may be related to (1) the unexpectedly high abundance of the $C_{31}$ homologues in these samples, combined with (2) lower decomposition of root alkanes when compared with shoot alkanes.

Lipid specific isotope composition control) exhibit $\delta^{13} \mathrm{C}$ values varying between $-36 \%$ and $-28 \%$ (Fig. $4 \mathrm{a}$ ), in agreement with literature on soil lipids (Huang et al. 1996; Chikaraishi \& Naraoka 2006; Mendez-Millan et al. 2014; Feakins et al. 2018). While apolar lipids of the casts from the mesocosm with earthworm but without plant residue (cast-control) display specific isotope compositions similar to the reference soil (-36\%o to $33 \%$, soil-NE-control, Fig. 4b), that of the underlying soil (soil-E-control) appear ${ }^{13} \mathrm{C}$-enriched with 
respect to the reference soil (-34\%o to $-9 \%$, Fig. $4 \mathrm{~b})$. This ${ }^{13} \mathrm{C}$-enrichment is the highest for the $\mathrm{C}_{21}-\mathrm{C}_{27}$ alkanes (+11\%o to $+19 \%$ with respect to the reference soil). As no ${ }^{13} \mathrm{C}$-labelled residue was applied to this mesocosm, this pattern is probably related to earthworm activity, based on the following two facts. First, the ${ }^{13} \mathrm{C}$-enrichment of soil alkanes may result, at least partially, from the preferential ingestion of soil fractions rich in plant $\mathrm{OM}$ that is naturally ${ }^{13} \mathrm{C}$-depleted with respect to bulk soil, thus leading to apparent ${ }^{13} \mathrm{C}$-enrichment of the remaining alkanes. Although, undetectable at bulk OM level (Vidal et al. 2017), such enrichment, would be especially noticeable at specific alkane level, as plant lipids are the main source of long-chain alkanes in soil. Secondly, the ${ }^{13} \mathrm{C}$-enrichment of soil alkane in Soil-E-Control when compared with Soil-NE-Control may be indirectly related to the production of carbonate granules in earthworm specialized glands (Dotterweich 1933; Versteegh et al. 2014). Indeed, the carbon of the granules comes partly from atmospheric $\mathrm{CO}_{2}$ that is ${ }^{13} \mathrm{C}$-enriched with respect to OM (Canti 2009), and $\mathrm{C}_{13}-\mathrm{C}_{38}$ n-alkanes were previously reported in $L$. terrestris lipids (Nooner et al. 1973; Stefanovic \& Djurdjic 1976).

In undegraded plant residues, alkanes displayed very different $\delta^{13} \mathrm{C}$ values according to chain length: specific alkane isotope compositions range between $+21 \%$ ond $+1502 \%$ in shoots, and between $+679 \%$ and $+1672 \%$ in roots (Fig. $4 \mathrm{c}$ and $4 \mathrm{f}$ ). As previously reported at the bulk scale for ${ }^{13} \mathrm{C}$-labelled leaves (Nguyen Tu et al. 2013), this $\delta^{13} \mathrm{C}$ range is much wider than that generally reported for natural plant alkanes (ca. $\leq 10 \%$ ). Such a wide range probably results from large variations in the ${ }^{13} \mathrm{C}$-content of the growth chamber, which are common during plant labeling experiments (Nguyen Tu et al. 2013; Soong et al. 2014). In addition, this variability was also probably driven by the natural variability of isotope fractionation processes within a given plant, such as that due to organ position (Waring \& Silvester 1994; Lockheart et al. 1997), and/or by the heterogeneity of stomatal aperture distribution naturally occurring in leaves (i.e. stomatal patchiness; Pospíšilová \& Šantrůček 1994; Beyschag \& Eckstein 1997). Accordingly, the following discussion is mainly based on comparisons of isotope compositions of a given homologue for a mesocosm and that of the relevant undegraded plant residue. 
313 isotope composition varying between $-33 \%$ and $+25 \%$ with shoots, and between $-31 \%$ and $+85 \%$ o 314 with roots (Fig. 4d and 4g). Alkane specific isotope compositions thus clearly point to incorporation, in soil, of the carbon derived from labelled plant residue. The hopene and the triterpenone also depict some incorporation of labelled carbon with specific $\delta^{13} \mathrm{C}$ values ranging from $+25 \%$ o to $+230 \%$ o (Fig. $4 \mathrm{~d}$ and $4 \mathrm{~g}$ ). Incorporation of ${ }^{13} \mathrm{C}$ in the soil triterpenone is likely due to the degradation of ${ }^{13} \mathrm{C}$ labelled plant triterpenol and subsequent contribution of its degradation product to the soil triterpenone pool. In both mesocosms with labelled plant residue and without earthworm, hopene is the most labelled lipid, showing that carbon from degrading plants is assimilated by soil bacteria. Soil lipids from the mesocosms with labelled plant residues and earthworms display ${ }^{13} \mathrm{C}-$ enrichment similar to that of mesocosms without earthworms: their specific isotope compositions vary between $-37 \%$ and $+10 \%$ for the shoot mesocosm, and between $-32 \%$ and $+72 \%$ or the root mesocosm (Fig. 4e and 4h). Here again, compound specific isotope measurements point to incorporation of the labelled carbon in soils. Cast lipids appear even more ${ }^{13} \mathrm{C}$-labelled than the corresponding soil with specific $\delta^{13} \mathrm{C}$ values ranging from $-31 \%$ o to $+426 \%$ for the shoot mesocosm, and from $-18 \%$ o to $+501 \%$ for the root mesocosm (Fig. 4 e and $4 \mathrm{~h}$ ). These results thus provide isotope evidence for the preferential incorporation of fresh plant residues in earthworm casts and for their persistence after one year of incubation.

\section{Carbon derived from the labelled plant residues}

Differences in the ${ }^{13} \mathrm{C}$-content of shoot and root residues precludes advanced conclusions based on direct comparison of $\delta^{13} \mathrm{C}$ values of the considered mesocosms. Hence, the proportion of $\mathrm{C}$ derived from the labelled plant residues in the soil or casts lipids $\left(C_{l a b}\right)$, was estimated, as a first approximation, according to the simplified equation (Balesdent \& Mariotti 1996):

$$
C_{\text {lab }}(\%)=\left[\left(\delta_{s}-\delta_{c}\right) /\left(\delta_{1}-\delta_{c}\right)\right] \times 100
$$

337 where $\delta_{s}$ is the $\delta^{13} \mathrm{C}$ value of soil or cast samples with labelled residue, $\delta_{c}$ is the $\delta^{13} \mathrm{C}$ value of the 
control soil or cast sample without plant residue and $\delta_{l}$ is the $\delta^{13} \mathrm{C}$ value of the labelled residue. As the pentacyclic triterpenes are absent from the plant residue, the denominator was approximated to:

- the mean alkane denominator for the triterpenone that is a typical plant lipid, similarly to mediumand long-chain alkanes;

- the bulk sample denominator for the hopene, as this bacterial biomarker is synthesized from nonlinear molecules.

$C_{\text {lab }}$ appears variable among apolar lipids, varying from $-6 \%$ to $+30 \%$ for a mean value of $+7 \%$

(Fig. 5 and Online Resource 2 for detailed data of alkanes). The few unusual negative values correspond to the less abundant alkanes $\left(C_{23}\right.$ and $\left.C_{25}\right)$ of the soil of the mesocosm with earthworms and shoot residue (soil-E-shoot). They are likely due, to the relative ${ }^{13} \mathrm{C}$-enrichment of the soil-Econtrol with respect to soil-NE-control (denominator of the equation). In addition, the negative $\mathrm{C}_{\text {lab }}$ values also probably reflect extensive degradation of these alkanes, especially those from the ${ }^{13} \mathrm{C}$ labelled residues, as shoot biomass degrades relatively quickly (Rasse et al. 2005). Most of the $C_{\text {lab }}$ values calculated for apolar lipids are positive, evidencing incorporation of carbon derived from the labelled plant residues in the lipid pool. They fall in the range of that previously found on bulk samples from the same experiment (1-13\%, Vidal et al. 2017). At first glance, this suggests that apolar lipids behave similarly to bulk OM, in spite of the relative recalcitrance of their chemical structure (i.e. due to aliphaticity, polycyclicity or no or few functional group prone to degradation, such as hydroxyl and carboxyl groups). However, lipid $C_{\text {lab }}$ varies in a wider range than that of bulk samples, with different pattern according to their relative abundance and chemical structure, as well as the presence of earthworm and/or plant residue in mesocosms.

Whatever plant residue type and apolar lipid constituent, the proportion of $\mathrm{C}$ derived from the labelled residue tends to follow the same pattern according to sample type (Fig. 5):

$C_{\text {lab }}$ (cast) $\geq C_{\text {lab }}$ (soil without earthworm) $\geq C_{\text {lab }}$ (soil with earthworm). According to the feeding ecology of $L$. terrestris, more labelled carbon is incorporated in its casts than in the underlying soil. The 
proportion of $\mathrm{C}$ derived from the labelled residue results from the balance between residue incorporation and its degradation in the sample. Previous chemical and microscopic characterizations of earthworm casts from the same experiment showed that they underwent two distinct transformation phases (Vidal et al. 2016a; 2019): (1) a phase dominated by plant residue incorporation during the first two months and then (2) a phase marked by decomposition of plant $\mathrm{OM}$ and formation of organomineral associations. Additionally, above OEP calculation showed that alkanes were less degraded in casts than in the surrounding soils. Taken together, these results suggest that besides higher incorporation of plant residues, earthworms may also induce a better preservation of plant alkanes in their casts than in soils at the longer term. In the same way, the intermediate ${ }^{13} \mathrm{C}$-incorporation level of apolar lipids in the soils without earthworm may suggest lower decomposition of ${ }^{13} \mathrm{C}$-residues when compared with the mesocosm with earthworm, in agreement with previous conclusions on bulk OM (Vidal et al. 2017). In the soils without earthworm, apolar lipid $\mathrm{C}_{\text {lab }}$ is higher for the mesocosm with root residues than for that with shoot residues (Fig. 5). This is also the case in soils with earthworms, although to a lesser extent. Combined with higher OEP for root vs shoot mesocosms, these findings may further suggest that root lipids are less degraded than shoot lipids, as previously found on bulk OM from the same experiment (Vidal et al. 2017). The difference, in the molecular structure of lipids, between root and shoot residues is too small to account for such contrasted $\mathrm{C}_{\text {lab. }}$. More likely, such a better preservation for root lipids may be due to the better preservation of bulk root tissues, in agreement with the higher recalcitrance of root tissues vs shoot tissues, often mentioned in literature (Kögel-Knabner 2002; Shi et al. 2013). Additionally, it may be due to the lower palatability of roots vs shoots, the latter being generally favored by earthworms for feeding (Bouché and Kretzschmar 1974; Cortez 1998; Curry and Schmidt 2007). In any case, it should be noted that in the present study, the intrinsic properties of plant residues is probably the main responsible for this difference, and not their availability/accessibility as often mentioned to explain root vs. shoot preservation difference. Indeed, both plant residues were introduced in the mesocosms in the same 
way, i.e. deposited on top. Conversely, no marked difference in cast $\mathrm{C}_{\mathrm{lab}}$ can be evidenced between root and shoot mesocosms suggesting that plant OM assimilation by earthworms smooths the difference between both residue types, as previously found on bulk OM from the same experiment (Vidal et al. 2017).

Within a given sample, $C_{\text {lab }}$ is maximal for either $C_{29}$ alkane or hopene, and minimal for the less abundant alkane measured (Online Resource 3). Proportionality between alkane abundance and $\mathrm{C}_{\mathrm{lab}}$ is likely related to mass balance. High $\mathrm{C}_{\mathrm{lab}}$ for hopene confirms intense assimilation of ${ }^{13} \mathrm{C}$-labelled carbon by soil bacteria, which activity was probably stimulated by the deposition of undegraded ${ }^{13} \mathrm{C}$ residues onto the mesocosms at the beginning of the experiment. These results obtained from $20 \mathrm{~g}$ of soil or cast samples, also substantiate observations by nanoSIMS of ${ }^{13} \mathrm{C}$-labelled bacteria on few $\mu \mathrm{g}$ of samples from same mesocosms (Vidal et al. 2016b, 2019). High incorporation of ${ }^{13} \mathrm{C}$-labelled carbon in this bacterial biomarker further provides molecular evidence that microorganisms are key recyclers of plant OM in soils. As a result, this one-year experiment support bacteria and other microorganisms as substantial source of OM in soil as acknowledged for a few years (Schaeffer et al. 2015; Kögel-Knabner 2017). Hopene corresponds, at least partly, to the degradation product of more functionalized hopanoids (Innes et al. 1997; Peters et al. 2005) and several bacterial remains were identified through microscope examination of the present samples (Vidal et al. 2019). Hence, hopene is probably typical of both bacterial living biomass and necromass, at least for the present mesocosms. As OM degradation is the dominant process in the mesocosms after one-year incubation (Vidal et al. 2016a, 2019), higher $C_{\text {lab }}$ for hopene than alkanes further suggests less degradation and better preservation of bacterial living biomass and necromass than initial plant OM. In other words, these results tend to support that on the year-scale, organic carbon may be efficiently sequestrated in soils as bacterial necromass (Liang and Balser 2011; Miltner et al. 2012).

\section{Conclusion}


In the present study, we investigated the impact of earthworms on soil lipid composition, in

the presence of root or shoot residues, after one year of incubation. In soils and casts, total lipid extracts were dominated by markers from past plant inputs, hiding the signal from recently incorporated OM. Except for the presence of arachidonic acid in casts while it was absent in soil, we depicted no impact of earthworms and plant residue type on soil total lipid extracts. However, the use of the molecular and compound-specific isotope composition of apolar lipids revealed differences between samples. Higher odd-over-even predominance and proportion of carbon derived from the labelled residues in cast alkanes with respect to soil suggested higher incorporation of plant residues and/or enhanced preservation of plant apolar lipids in earthworm casts.

The high level of plant-derived carbon in casts was associated with a high ${ }^{13} \mathrm{C}$-incorporation level for the bacterial biomarker hopene, confirming higher bacterial presence in casts than in soils. Hopene being a marker for both living biomass and bacterial necromass, we can suggest the importance of both living and dead microorganism in casts. Further efforts should be achieved to depict the contribution of microbial necromass in organic carbon sequestration in soil and casts. In this one year experiment, molecular and isotope features of soil lipids pointed towards a higher contribution of root-derived lipids compared with shoot-derived lipids, likely reflecting the lower decomposition rate of root lipids. This difference was lowered in casts suggesting that although substantially incorporated and preserved in casts, apolar lipids undergo some degradation that probably smoothed the difference between root and shoot residues. In soils, apolar lipids roughly followed decomposition trends similar to that of bulk $\mathrm{OM}$, which was not always the case in casts, likely reflecting the influence of both molecular properties of OM and soil (micro)structure on OM decomposition. Finally, these first results obtained from a one year experiment suggest that, at larger time scale, it is can be important to differentiate the influence of earthworms on soils from that on casts. Indeed, casts represent a specific microenvironment where both plant accumulation and preservation, as well as microbial activity are enhanced. 


\section{Acknowledgements}

The study was funded by an EC2CO (CNRS-INSU) grant that was greatly appreciated. We are grateful to Patrick Dumont of Sorbonne Université greenhouse facilities for access to the experimental chamber and technical support. Elise Canolle and Anne-Sophie Permal are thanked for their help in preparing the lipids during their internship at METIS. We are indebted to Christelle Anquetil and Véronique Vaury for GC-MS and EA-IRMS analyses, respectively. CSIA were obtained from the ALYSES facility (IRD-SU) that was supported by grants from Région Ile-de-France. Thanks are also due to the two anonymous referees who provided constructive reviews of the manuscript.

\section{References}

Albro PW, Schroeder JL, Corbett JT (1992) Lipids of the earthworm Lumbricus terrestris. Lipids 27, $136-143$

Alexander M (1981) Biodegradation of chemicals of environmental concern. Science 211, 132-138

Amblès A, Jambu P, Parlanti E, Joffre J, Riffe C, 1994. Incorporation of natural monoacids from plant residues into an hydromorphic forest podzol. Eur J Soil Sci 45:175-182

Angst Š, Mueller CW, Cajthaml T, Angst G, Lhotáková Z, Bartuška M, Špaldoňová A, Frouz J (2017) Stabilization of soil organic matter by earthworms is connected with physical protection rather than with chemical changes of organic matter. Geoderma 289:29-35

Bahri H, Dignac MF, Rumpel C, Rasse D, Chenu C, Mariotti A (2006) Lignin turnover kinetics in an agricultural soil is monomer specific. Soil Biol Biochem 38:1977-1988

Balesdent J, Mariotti A (1996) Measurement of soil organic matter turnover using ${ }^{13} \mathrm{C}$ natural abundance. In: Boutton TW and Yamasaki SI (eds) Mass Spectrometry of Soils. Marcel Dekker Inc, New York, pp 83-111

Beyschlag W, Eckstein J (1997) Stomatal patchiness. Prog. Bot. 59:283-298.

Bossuyt H, Six J, Hendrix PF (2005) Protection of soil carbon by microaggregates within earthworm casts. Soil Biol Biochem 37:251-258. 
Bouché M, Kretzschmar A (1974) Fonction des lombriciens; Il: Recherches méthodologiques pour l'analyse du sol ingéré (étude du peuplement de la station RCP-165/PBI). Rev écol biol sol 11:127-139

Boutton TW (1996) Stable carbon isotope ratios of organic matter and their use as indicators of vegetation and climate changes. In: Boutton TW and Yamasaki SI (eds) Mass Spectrometry of Soils. Marcel Dekker Inc, New York, pp 47-82

Brown GG, Barois I, Lavelle P (2000) Regulation of soil organic matter dynamics and microbial activityin the drilosphere and the role of interactions with other edaphic functional domains. Eur J Soil Biol 36:177-198

Buggle B, Wiensenberg GL, Glaser B (2010) Is there a possibility to correct fossil n-alkane data for postsedimentary alteration effects? Appl Geochem 25: 947-957.

Bull ID, van Bergen PF, Nott CJ, Poulton PR, Evershed RP (2000) Organic geochemical studies of soils from Rothamsted classical experiments-V. The fate of lipids in different long-term experiments. Org Geochem 31:389-408

Canti MG (2009) Experiments on the origin of ${ }^{13} \mathrm{C}$ in the calcium carbonate granules produced by the earthworm Lumbricus terrestris. Soil Biol Biochem 41:2588-2592

Chikaraishi Y, Naraoka H (2006) Carbon and hydrogen isotope variation of plant biomarkers in a plant-soil system. Chem Geol 231:190-202

Cortez J (1998) Field decomposition of leaf litters: relationships between decomposition rates and soil moisture, soil temperature and earthworm activity. Soil Biol Biochem 30:783-793.

Crow SE, Filley TR, McCormick M, Szlávecz K, Stott DE, Gamblin D, Conyers G (2009) Earthworms, stand age, and species composition interact to influence particulate organic matter chemistry during forest succession. Biogeochemistry 92:61-82

Curry JP, Schmidt O (2007) The feeding ecology of earthworms - A review. Pedobiologia 50:463-477

Derrien D, Marol C, Balabane M, Balesdent J (2006) The turnover of carbohydrate carbon in a cultivated soil estimated by ${ }^{13} \mathrm{C}$ natural abundances. Eur J Soil Sci $57: 547-557$ 
Dinel H, Schnitzer M (1990) Soil lipids: origin, nature, content, decomposition, and effect on soil physical properties. In: Bollag JM, Stotzky G (eds) Soil Biochemistry. Marcel Dekker, New York, pp 397-429

Dotterweich H (1933) Die Funktion tierischer Kalkablagerungen als Pufferreserve im Dienste der Reaktionsregulation. Die Kalkdrusen des Regenwurms. Pflugers Arch Geschicte Physiol 232:263-286.

Eglinton G, Hamilton RJ (1967) Leaf epicuticular waxes. Science 156:1322-1335

El-Otmani M, Coggins CW (1985) Fruit development and growth regulator effects on normal alkanes of "Washington" navel orange fruit epicuticular wax. J Agric Food Chem 33:656-663

Fahey TJ, Yavitt JB, Sherman RE, Maerz JC, Groffman PM, Fisk MC, Bohlen PJ (2013) Earthworm effects on the incorporation of litter $\mathrm{C}$ and $\mathrm{N}$ into soil organic matter in a sugar maple forest. Ecol Appl 23:1185-1201

Feakins SJ, Wu MS, Ponton C, Galy V, West AJ (2018) Dual isotope evidence for sedimentary integration of plant wax biomarkers across an Andes-Amazon elevation transect. Geochim Cosmochim Acta 242:64-81

Filley TR, McCormick MK, Crow SE, Szlavecz K, Whigham DF, Johnston CT, van den Heuvel RN (2008) Comparison of the chemical alteration trajectory of Liriodendron tulipifera L. leaf litter among forests with different earthworm abundance. J Geophys Res 113:1-14

Fontaine S, Bardoux G, Benest D, Verdier B, Mariotti A, Abbadie L (2004) Carbon input to soil may decrease soil carbon content. Ecol. Lett. 7:314-320

Fonte SJ, Quintero DC, Velásquez E, Lavelle P (2012) Interactive effects of plants and earthworms on the physical stabilization of soil organic matter in aggregates. Plant Soil 359:205-214.

Frouz J, Špaldoňová A, Lhotáková Z, Cajthaml T (2015) Major mechanisms contributing to the macrofauna-mediated slow down of litter decomposition. Soil Biol Biochem 91:23-31

Gocke M, Kuzyakov Y, Wiesenberg GLB (2013) Differentiation of plant derived organic matter in soil, loess and rhizoliths based on $n$-alkane molecular proxies. Biogeochemistry 112:23-40 
Gonzalez-Vila FJ (1995) Alkane biomarkers. Geochemichal significance and application in oil shale geochemistry. In: Snape C (ed) Composition, Geochemistry and Conversion of Oil Shales. NATO ASI Series C455:51-68

Guggenberger G, Thomas RJ, Zech W (1996) Soil organic matter within earthworm casts of an anecicendogeic tropical pasture community, Colombia. Appl Soil Ecol 3:263-274

Gülz PG, Müller E, Prasad RBN (1991) Developmental and seasonal variations in the epicuticular waves of Tilia tomentosa leaves. Phytochemistry 30:769-773

Harwood JL, Russel NJ (1984) Lipids in plants and microbes. George Allen \& Unwin, London.

Hoefs JL, Rijpstra WI, Sinninghe Damsté JS (2002) The influence of oxic degradation on the sedimentary biomarker record I: Evidence from Madeira Abyssal Plain turbidites. Geochim. Cosmochim. Acta 66:2719-2735.

Hong HN, Rumpel C, Henry des Tureaux T, Bardoux G, Billou D, Tran Duc T, Jouquet P (2011) How do earthworms influence organic matter quantity and quality in tropical soils? Soil Biol Biochem $43: 223-230$.

Huang X, Wang C, Zhang J, Wiesenberg GLB, Zhang Z, Xie S (2011) Comparison of free lipid compositions between roots and leaves of plants in the Dajiuhu Peatland, central China. Geochem J 45:365-373

Huang Y, Bol R, Harkness DD, Ineson P, Eglinton G (1996) Post-glacial variations in distributions, ${ }^{13} \mathrm{C}$, ${ }^{14} \mathrm{C}$ contents of aliphatic hydrocarbons and bulk organic matter in three types of British acid upland soils. Org Geochem 24:273-287

Innes HE, Bishop AN, Head IM, Farrimond P (1997) Preservation and diagenesis of hopanoids in Recent lacustrine sediments of Priest Pot, England. Org Geochem 26:565-576

Jambu P, Fustec E, Jacquesy R (1978) Les lipides des sols: nature, origine, évolution, propriétés. Sci Sol Bull AFES 4:229-2040

Jandl G, Leinweber P, Schulten HR, Ekschmitt K (2005) Contribution of primary organic matter to the fatty acid pool in agricultural soils. Soil Biol Biochem 37:1033-1041. 
Jansen B, Haussmann NS, Tonneijck FH, Verstraten JM, de Voogt P (2008) Characteristic straightchain lipid ratios as a quick method to assess past forest-páramo transitions in the Ecuadorian Andes. Palaeogeogr Palaeoclimatol Palaeoecol 262:129-139

Jansen B, Nierop KGJ, Hageman JA, Cleef AM, Verstraten JM (2006) The straight-chain lipid biomarker composition of plant species responsible for the dominant biomass production along two altitudinal transects in the Ecuadorian Andes. Org Geochem 37:1514-1536

Jégou D, Cluzeau D, Hallaire V, Balesdent J, Tréhen P (2000) Burrowing activity of the earthworms Lumbricus terrestris and Aporrectodea giardi and consequences on C transfers in soil. Eur J Soil Biol 36:27-34

Jégou D, Schrader S, Diestel H, Cluzeau D (2001) Morphological, physical and biochemical characteristics of burrow walls formed by earthworms. Appl Soil Ecol 17:165-174

Jobbágy EG, Jackson RB (2000) The vertical distribution of soil organic carbon and its relation to climate and vegetation. Ecol Appl 10:423-436

Kelleher BP, Simpson AJ (2006) Humic Substances in Soils: Are They Really Chemically Distinct? Environ Sci Technol 40:4605-4611

Kögel-Knabner I (2002) The macromolecular organic composition of plant and microbial residues as inputs to soil organic matter. Soil Biol Biochem 34:139-162

Kögel-Knabner I (2017) The macromolecular organic composition of plant and microbial residues as inputs to soil organic matter: Fourteen years on. Soil Biol Biochem 105:A3-A8

Kolattukudy PE, Croteau R, Buckner JS (1976) Biochemistry of plant waxes. In: Kolattukudy PE (ed) Chemistry and Biochemistry of Natural Waxes. Elsevier, Amsterdam, pp 290-347

Kuzyakov Y (2010) Priming effects: interactions between living and dead organic matter. Soil Biol. Biochem. 42:1363-1371

Lavelle P, Martin A (1992) Small-scale and large-scale effects of endogeic earthworms on soil organic matter dynamics in soils of the humid tropics. Soil Biol Biochem 24:1491-1498 
Lavelle P, Pashanasi B, Charpentier F, Rossi JP, Derouard L, André J, Ponge JF, Bernier N (1998) Largescale effects of earthworms on soil organic matter and nutrient dynamics. In: Edwards CA (ed) Earthworm Ecology. Boca Raton, Boca Raton, pp 103-122

Lee KE (1985) Earthworms their ecology and relationships with soils and land use. Academic Press, Sydney.

Li R, Fan J, Xue J, Meyers PA (2017) Effects of early diagenesis on molecular distributions and carbon isotopic compositions of leaf wax long chain biomarker $n$-alkanes: Comparison of two oneyear-long burial experiments. Org Geochem 104:8-18

Li R, Meyers PA, Fan J, Xue J (2016) Monthly changes in chain length distributions and stable carbon isotope composition of leaf $n$-alkanes during growth of the bamboo Dendrocalamus ronganensis and the grass Setaria viridis. Org Geochem 101:72-81

Liang C, Balser TC (2011) Microbial production of recalcitrant organic matter in global soils: implications for productivity and climate policy. Nat Rev Microbiol 9:75-75

Lichtfouse E, Chenu C, Baudin F, Leblond C, Da Silva M, Behar F, Derenne S, Largeau C, Wehrung P, Albrecht P (1998) A novel pathway of soil organic matter formation by selective preservation of resistant straight-chain biopolymers: chemical and isotope evidence. Org Geochem 28:411-415

Lockheart MJ, van Bergen PF, Evershed RP (1997) Variations in the stable carbon isotope composition of individual lipids from the leaves of modern angiosperms: implications for the study of higher plant-derived sedimentary organic matter. Org. geochem. 26:137-153.

Lubbers IM, van Groenigen KJ, Fonte SJ, Six J, Brussaard L, van Groenigen JW (2013) Greenhouse-gas emissions from soils increased by earthworms. Nat Clim Change 3:187-194

Lutzow M v, Kogel-Knabner I, Ekschmitt K, Matzner E, Guggenberger G, Marschner B, Flessa H (2006) Stabilization of organic matter in temperate soils: mechanisms and their relevance under different soil conditions - a review. Eur J Soil Sci 57:426-445 
Malossini F, Piasentier E, Bovolenta S (1990) $n$-alkane content of some forages. J Sci Food Agric

$$
\text { 53:405-409 }
$$

Mariotti A, Balesdent J, (1990) ${ }^{13} \mathrm{C}$ natural abundance as a tracer of soil organic matter turnover and paleoenvironment dynamics. Chem Geol 84:217-219

Martin A (1991) Short- and long-term effects of the endogeic earthworm Millsonia anomala (Omodeo) (Megascolecidæ, Oligochæta) of tropical savannas, on soil organic matter. Biol Fertil Soils 11:234-238

Mendez-Millan M, Dignac MF, Rumpel C, Rasse DP, Derenne S (2010) Molecular dynamics of shoot vs. root biomarkers in an agricultural soil estimated by natural abundance ${ }^{13} \mathrm{C}$ labelling. Soil Biol Biochem 42:169-177

Mendez-Millan M, Nguyen Tu TT, Balesdent J, Derenne S, Derrien D, Egasse C, Thongo M'Bou A, Zeller B, Hatté C (2014) Compound-specific ${ }^{13} \mathrm{C}$ and ${ }^{14} \mathrm{C}$ measurements improve the understanding of soil organic matter dynamics. Biogeochemistry 118:205-223

Miltner A, Bombach P, Schmidt-Brücken B, Kästner M (2012) SOM genesis: microbial biomass as a significant source. Biogeochemistry 111:41-55.

Mueller KE, Polissar PJ, Oleksyn J, Freeman KH (2012) Differentiating temperate tree species and their organs using lipid biomarkers in leaves, roots and soil. Org Geochem 52 :130-141

Nguyen Tu TT, Biron P, Maseyk K, Richard, P, Zeller B, Quénéa K, Alexis M, Bardoux G, Vaury V, Girardin C, Pouteau V, Billiou D, Bariac T (2013) Variability of ${ }^{13}$ C-labeling in plant leaves. Rapid Commun Mass Spectrom 27:1961-1968.

Nguyen Tu TT, Egasse C, Zeller B, Bardoux G, Biron P, Ponge JF, David B, Derenne S (2011) Early degradation of plant alkanes in soils: A litterbag experiment using ${ }^{13} \mathrm{C}$-labelled leaves. Soil Biol Biochem 43:2222-2228.

Nierop KGJ, Jansen B, Hageman JA, Verstraten JM (2006) The Complementarity of Extractable and Ester-Bound Lipids in a Soil Profile Under Pine. Plant Soil 286:269-285. 
Nooner DW, Oro J, Cerbulis J (1973) Paraffinic hydrocarbon composition of earthworms (Lumbricus terrestris). Lipids 8:489-492

Otto A, Shunthirasingham C, Simpson MJ (2005) A comparison of plant and microbial biomarkers in grassland soils from the Prairie Ecozone of Canada. Org Geochem 36:425-448

Ourisson G, Albrecht P, Rohmer M (1979) Palaeobiochemistry and biochemistry of a group of natural products. Pure Appl Chem 51:709-729

Peters KE, Walters JM, Moldowan JM (2005) The Biomarker Guide, 2nd ed. Cambridge University Press, Cambridge

Pospišilová J, Šantrůček J (1994) Stomatal patchiness. Biol. Plantarum. 36:481-510

Quénéa K, Derenne S, Largeau C, Rumpel C, Mariotti A (2004) Variation in lipid relative abundance and composition among different particle size fractions of a forest soil. Org Geochem $35: 1355-1370$

Quénéa K, Largeau G, Derenne S, Spaccini R, Bardoux G, Mariotti A (2006) Molecular and isotopic study of lipids in particle size fractions of a sandy cultivated soil (Cestas cultivation sequence, southwest of France) : Sources, degradation and comparison with Cestas forest soil. Org Geochem 3:20-44.

Quénéa K, Mathieu J, Derenne S (2012) Soil lipids from accelerated solvent extraction: Influence of temperature and solvent on extract composition. Org Geochem 44:45-52

Rasse DP, Rumpel C, Dignac MF (2005) Is soil carbon mostly root carbon? Mechanisms for a specific stabilisation. Plant Soil 269:341-356

Rawlins AJ, Bull ID, Poirier N, Ineson P, Evershed RP (2006) The biochemical transformation of oak (Quercus robur) leaf litter consumed by the pill millipede (Glomersi marginata). Soil Biol Biochem 38:1063-1076

Sampedro L, Whalen JK (2007) Changes in the fatty acid profiles through the digestive tract of the earthworm Lumbricus terrestris L. Appl Soil Ecol 35:226-236 
Schaefer IK, Lanny V, Franke J., Eglinton TI, Zech M, Vysloužilová B, Zech R (2016) Leaf waxes in litter and topsoils along a European transect. Soil 2: 551-564

Schaefer M, Petersen SO, Filser J (2005) Effects of Lumbricus terrestris, Allolobophora chlorotica and Eisenia fetida on microbial community dynamics in oil-contaminated soil. Soil Biol Biochem $37: 2065-2076$

Schaeffer A, Nannipieri P, Kästner M, Schmidt B, Botterweck J (2015) From humic substances to soil organic matter-microbial contributions. In honour of Konrad Haider and James P. Martin for their outstanding research contribution to soil science. J Soils Sediments $15: 1865-1881$

Schmidt MWI, Torn MS, Abiven S, Dittmar T, Guggenberger G, Janssens IA, Kleber M, Kogel-Knabner I, Lehmann J, Manning DAC, Nannipieri P, Rasse DP, Weiner S, Trumbore SE (2011) Persistence of soil organic matter as an ecosystem property. Nature 478:49-56

Shi A, Penfold C, Marschner P (2013) Decomposition of roots and shoots of perennial grasses and annual barley - separately or in two residue mixes. Biol Fertil Soils 49:673-680

Six J, Bossuyt H, Degryze S, Denef K (2004) A history of research on the link between (micro)aggregates, soil biota, and soil organic matter dynamics. Soil Tillage Res 79:7-31

Soong JL, Reuss D, Pinney C, Boyack T, Haddix ML, Stewart CE, Cotrufo MF (2014) Design and operation of a continuous ${ }^{13} \mathrm{C}$ and ${ }^{15} \mathrm{~N}$ labeling chamber for uniform or differential, metabolic and structural, plant isotope labeling. J. vis. exp. 83: e51117.

Srivastava K, Wiesenberg GLB (2018) Severe drought-influenced composition and $\delta^{13} \mathrm{C}$ of plant and soil $n$-alkanes in model temperate grassland and heathland ecosystems. Org Geochem $116: 77-89$

Stefanovic D, Djurdjic V (1976) An investigation of lipids from Lumbricus terrestris. I. Study of the hydrocarbon fraction. Glas - Srp Akad Nauka Umet Odeljenje Prir-Mat Nauka 39:53-66

Stromberger ME, Keith AM, Schmidt O (2012) Distinct microbial and faunal communities and translocated carbon in Lumbricus terrestris drilospheres. Soil Biol Biochem 46:155-162 
van Bergen PF, Flannery MB, Poulton PR, Evershed RP (1998) Organic geochemical studies of soils from Rothamsted experimental station: III. Nitrogen-containing oragnic matter in soil from Geescroft Wilderness. In: Stankiewicz BA, van Bergen PF (eds) Nitrogen-Containing Macromolecules in the Bio- and Geosphere. American Chemical Society Symposium Series 707:321-338.

Versteegh EAA, Black S, Hodson ME (2014) Environmental controls on the production of calcium carbonate by earthworms. Soil Biol Biochem 70:159-161

Vidal A, Quénéa K, Alexis M, Derenne S (2016a) Molecular fate of root and shoot litter on incorporation and decomposition in earthworm casts. Org Geochem 101:1-10

Vidal A, Remusat L, Watteau F, Derenne S, Quénéa K (2016b) Incorporation of ${ }^{13} \mathrm{C}$ labelled shoot residues in Lumbricus terrestris casts: A combination of transmission electron microscopy and nanoscale secondary ion mass spectrometry. Soil Biol Biochem 93:8-16

Vidal A, Quénéa K, Alexis M, Nguyen Tu TT, Mathieu J, Vaury V, Derenne S (2017) Fate of ${ }^{13} \mathrm{C}$ labelled root and shoot residues in soil and anecic earthworm casts: A mesocosm experiment. Geoderma 285:9-18

Vidal A, Watteau F, Rémusat L, Mueller CW, Nguyen Tu TT, Buegger F, Derenne S, Quénéa K (2019) Earthworm cast formation and development: a shift from plant litter to mineral associated organic matter. Front. environ. Sci. 7:55

Walthall CL, Hatfield J, Backlund P et al (2012) Climate change and agriculture in the United States: Effects and adaptation. USDA Technical Bulletin, Washington.

Wannigama GP, Volkman JK, Gillan FT, Nichols GJ, Johns RB (1981) A compaison of lipid components of the fresh and dead leaves and pneumatophores of the mangrove Avicennia marina. Phytochemistry 20:659-666

Waring RH, Silvester WB (1994) Variation in foliar $\delta^{13} \mathrm{C}$ values within the crowns of Pinus radiata trees. Tree Physiol. 14:1203-1213. 
696 Wiesenberg GLB, Dorodnikov M, Kuzyakov Y (2010) Source determination of lipids in bulk soil and soil density fractions after four years of wheat cropping. Geoderma 156:267-277

698 Wiesenberg GLB, Schwarzbauer J, Schmidt MWI, Schwark L (2004) Source and turnover of organic

699 matter in agricultural soils derived from $n$-alkane/ $n$-carboxylic acid compositions and Cisotope signatures. Org Geochem 35:1371-1393

701

Zangerlé A, Pando A, Lavelle P (2011) Do earthworms and roots cooperate to build soil macroaggregates? A microcosm experiment. Geoderma 167-168, 303-309

Zech M, Buggle B, Leiber K, Marković, Glaser B, Hambach U, Huwe B, Stevens T, Sümegi P, 
Table 1. Bulk geochemical characteristics of the sample studied: undegraded residues, soils and casts after one year of incubation.

\begin{tabular}{|c|c|c|c|c|c|c|c|}
\hline Sample name & $\begin{array}{l}\text { Figs. } 3 \\
\& 4^{\mathrm{a}}\end{array}$ & Residue & Earthworms & $\delta^{13} C_{\text {bulk }}{ }^{b}$ & $\begin{array}{c}\text { Lipid } \\
\text { content }^{c}\end{array}$ & $\begin{array}{c}\text { Alkane } \\
\text { content }^{\mathrm{d}}\end{array}$ & $\begin{array}{c}\text { Alkane } \\
\text { OEPe }\end{array}$ \\
\hline undeg-Shoot & c & Shoot & - & +1632.3 & 17.24 & 2.2 & 5.5 \\
\hline undeg-Root & $f$ & Root & - & +1323.5 & 3.88 & 1.3 & 5.1 \\
\hline soil-NE-Control & $a$ & No & No & -28.1 & 0.03 & 12.9 & 4.8 \\
\hline soil-NE-Shoot & d & Shoot & No & +23.3 & 0.03 & 13.4 & 4.0 \\
\hline soil-NE-Root & g & Root & No & +125.7 & 0.03 & 12.5 & 4.9 \\
\hline soil-E-Control & $\mathrm{b}$ & No & Yes & -28.1 & 0.05 & 10.4 & 3.9 \\
\hline cast-Control & $\mathrm{b}$ & No & Yes & -28.6 & 0.05 & 7.8 & 5.4 \\
\hline soil-E-Shoot & e & Shoot & Yes & -12.1 & 0.04 & 13.5 & 3.3 \\
\hline cast-Shoot & e & Shoot & Yes & +167.6 & 0.06 & 9.8 & 6.6 \\
\hline soil-E-Root & $\mathrm{h}$ & Root & Yes & +25.3 & 0.09 & 11.7 & 5.8 \\
\hline cast-Root & $\mathrm{h}$ & Root & Yes & +126.6 & 0.08 & 10.1 & 7.8 \\
\hline
\end{tabular}

711

a associated graph on Figs. 3 and 4;

713 b \%o, modified from Vidal et al. (2017);

714 ' weight $\%$ of dried sample;

715 d estimated alkane content assessed from area \% of the summed alkanes with respect to the

716 summed components of the total lipid chromatogram;

717 e odd-over-even carbon number predominance of alkanes. 
Figure 1. Total lon Chromatogram (TIC) trace for lipid extracts of $\mathbf{a}$, initial root residue and $\mathbf{b}$, initial shoot residue. Aromatic compounds (red symbols) including compounds with guiacyl structure (O), 3,4,5-trimethoxy benzaldehyde ( $\square$ ) and 3-(4-methoxyphenyl) 2-propenoic acid (O), and 4-methoxybenzoic acid ( $\left(\frac{\lambda}{2}\right)$; aliphatic compounds: $n$-alkanes (ه); $n$-alkanoic acids $(\diamond) ; n$-alkanedioic

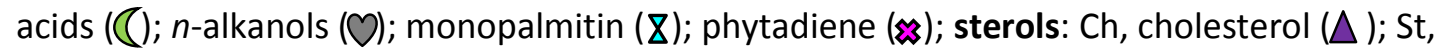
stigmasterol $(\Delta)$; Si, sitosterol $(\Delta)$. Numbers indicate chain length.

Figure 2. TIC trace for lipid extracts of $\mathbf{a}$, reference soil (soil-NE-control) and $\mathbf{b}$, cast (cast-control), after 54 weeks of experiment. 4-methoxybenzoic acid ( $\star \star t)$; $n$-alkanes (@); $n$-alkanoic acids $(\downarrow) ; \omega$ hydroxyalkanoic acids ( $)$; $n$-alkanols $(0)$; sterols: Ch, cholesterol ( $\Delta$ ); St, stigmasterol ( $\Delta$ ); $\mathrm{Si}$, sitosterol $(\boldsymbol{A})$. Numbers indicate chain length. $A$ focus was made on the qualitative differences observed between Control-NE and Cast-Control. As both samples were very similar, only the dominant molecules are indicated on the chromatogram of Cast-Control.

Figure 3. Molecular distribution of the apolar lipids extracted from undegraded residues, soils and casts of the mesocosms. a, soil-NE-Control; b, soil-E-Control (brown) and cast-Control (blue); c, undeg-shoot; d, soil-NE-Shoot; e, soil-E-Shoot (brown) and cast-Shoot (green); f, undeg-Root; g, soilNE-Root; $\mathbf{h}$, soil-E-Root (brown) and cast-Root (yellow). See table 1 for sample details. Relative abundances were normalized to the most abundant compound.

Figure 4. Specific isotope composition of the apolar lipids extracted from undegraded residues, soils and casts of the mesocosms. Isotope compositions are shown under logarithmic scale for easier comparison of the mesocosms with and without labelled residues [ $\left.\log _{10}\left(\delta^{13} \mathrm{C}+50\right)\right]$. a, soil-NEControl; b, soil-E-Control (brown) and cast-Control (blue); c, undeg-shoot; d, soil-NE-Shoot; e, soil-EShoot (brown) and cast-Shoot (green); f, undeg-Root; g, soil-NE-Root; h, soil-E-Root (brown) and castRoot (yellow). See table 1 for sample details. Exact isotope values are available in Online Resource 2

Figure 5. Proportion of carbon derived from the labelled residues $\left(\mathrm{C}_{\mathrm{lab}}\right)$ in the soils and casts incubated in the presence of earthworms. Alkane $C_{\text {lab }}$ corresponds to the weighted mean of $C_{21}, C_{23}$, 
Table 1. Bulk geochemical characteristics of the sample studied: undegraded residues, soils and casts after one year of incubation.

\begin{tabular}{|c|c|c|c|c|c|c|c|}
\hline Sample name & $\begin{array}{l}\text { Figs. } 3 \\
\& 4^{\mathrm{a}}\end{array}$ & Residue & Earthworms & $\delta^{13} C_{\text {bulk }}{ }^{b}$ & $\begin{array}{c}\text { Lipid } \\
\text { content }^{c}\end{array}$ & $\begin{array}{c}\text { Alkane } \\
\text { content }^{\mathrm{d}}\end{array}$ & $\begin{array}{c}\text { Alkane } \\
\text { OEPe }\end{array}$ \\
\hline undeg-Shoot & c & Shoot & - & +1632.3 & 17.24 & 2.2 & 5.5 \\
\hline undeg-Root & $f$ & Root & - & +1323.5 & 3.88 & 1.3 & 5.1 \\
\hline soil-NE-Control & $a$ & No & No & -28.1 & 0.03 & 12.9 & 4.8 \\
\hline soil-NE-Shoot & d & Shoot & No & +23.3 & 0.03 & 13.4 & 4.0 \\
\hline soil-NE-Root & g & Root & No & +125.7 & 0.03 & 12.5 & 4.9 \\
\hline soil-E-Control & $\mathrm{b}$ & No & Yes & -28.1 & 0.05 & 10.4 & 3.9 \\
\hline cast-Control & $\mathrm{b}$ & No & Yes & -28.6 & 0.05 & 7.8 & 5.4 \\
\hline soil-E-Shoot & e & Shoot & Yes & -12.1 & 0.04 & 13.5 & 3.3 \\
\hline cast-Shoot & e & Shoot & Yes & +167.6 & 0.06 & 9.8 & 6.6 \\
\hline soil-E-Root & $\mathrm{h}$ & Root & Yes & +25.3 & 0.09 & 11.7 & 5.8 \\
\hline cast-Root & $\mathrm{h}$ & Root & Yes & +126.6 & 0.08 & 10.1 & 7.8 \\
\hline
\end{tabular}

711

a associated graph on Figs. 3 and 4;

713 b \%o, modified from Vidal et al. (2017);

714 ' weight $\%$ of dried sample;

715 d estimated alkane content assessed from area \% of the summed alkanes with respect to the

716 summed components of the total lipid chromatogram;

717 e odd-over-even carbon number predominance of alkanes. 
Figure 1. Total lon Chromatogram (TIC) trace for lipid extracts of $\mathbf{a}$, initial root residue and $\mathbf{b}$, initial shoot residue. Aromatic compounds (red symbols) including compounds with guiacyl structure (O), 3,4,5-trimethoxy benzaldehyde ( $\square$ ) and 3-(4-methoxyphenyl) 2-propenoic acid (O), and 4-methoxybenzoic acid ( $\left(\frac{\lambda}{2}\right)$; aliphatic compounds: $n$-alkanes (ه); $n$-alkanoic acids $(\diamond) ; n$-alkanedioic

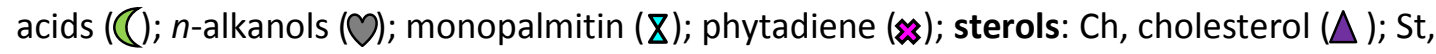
stigmasterol $(\Delta)$; Si, sitosterol $(\Delta)$. Numbers indicate chain length.

Figure 2. TIC trace for lipid extracts of $\mathbf{a}$, reference soil (soil-NE-control) and $\mathbf{b}$, cast (cast-control), after 54 weeks of experiment. 4-methoxybenzoic acid ( $\star \star t)$; $n$-alkanes (@); $n$-alkanoic acids $(\downarrow) ; \omega$ hydroxyalkanoic acids ( $)$; $n$-alkanols $(0)$; sterols: Ch, cholesterol ( $\Delta$ ); St, stigmasterol ( $\Delta$ ); $\mathrm{Si}$, sitosterol $(\boldsymbol{A})$. Numbers indicate chain length. $A$ focus was made on the qualitative differences observed between Control-NE and Cast-Control. As both samples were very similar, only the dominant molecules are indicated on the chromatogram of Cast-Control.

Figure 3. Molecular distribution of the apolar lipids extracted from undegraded residues, soils and casts of the mesocosms. a, soil-NE-Control; b, soil-E-Control (brown) and cast-Control (blue); c, undeg-shoot; d, soil-NE-Shoot; e, soil-E-Shoot (brown) and cast-Shoot (green); f, undeg-Root; g, soilNE-Root; $\mathbf{h}$, soil-E-Root (brown) and cast-Root (yellow). See table 1 for sample details. Relative abundances were normalized to the most abundant compound.

Figure 4. Specific isotope composition of the apolar lipids extracted from undegraded residues, soils and casts of the mesocosms. Isotope compositions are shown under logarithmic scale for easier comparison of the mesocosms with and without labelled residues [ $\left.\log _{10}\left(\delta^{13} \mathrm{C}+50\right)\right]$. a, soil-NEControl; b, soil-E-Control (brown) and cast-Control (blue); c, undeg-shoot; d, soil-NE-Shoot; e, soil-EShoot (brown) and cast-Shoot (green); f, undeg-Root; g, soil-NE-Root; h, soil-E-Root (brown) and castRoot (yellow). See table 1 for sample details. Exact isotope values are available in Online Resource 2

Figure 5. Proportion of carbon derived from the labelled residues $\left(C_{1 a b}\right)$ in the soils and casts incubated in the presence of earthworms. Alkane $C_{\text {lab }}$ corresponds to the weighted mean of $C_{21}, C_{23}$, 
Figure 1

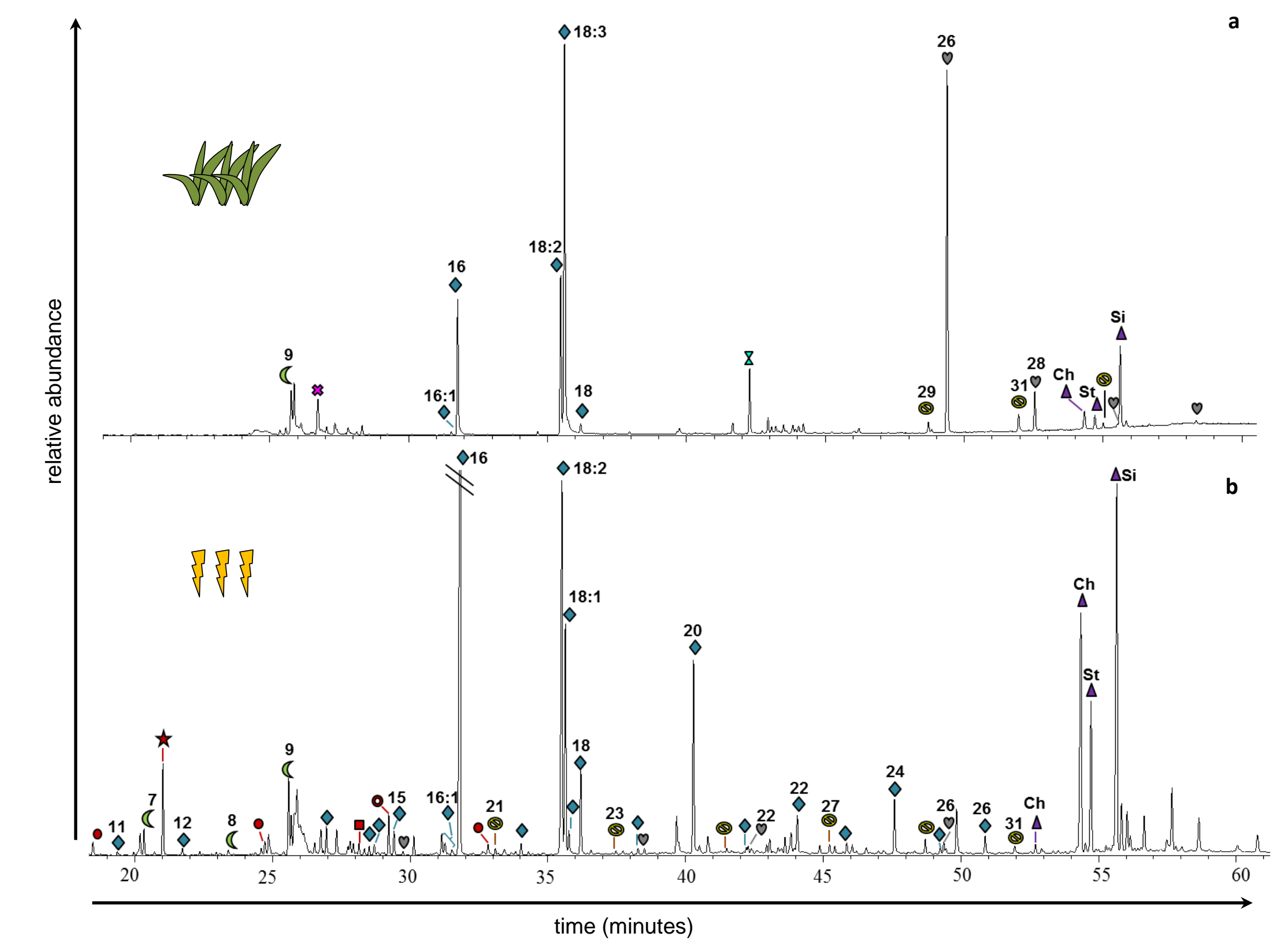


Figure 2

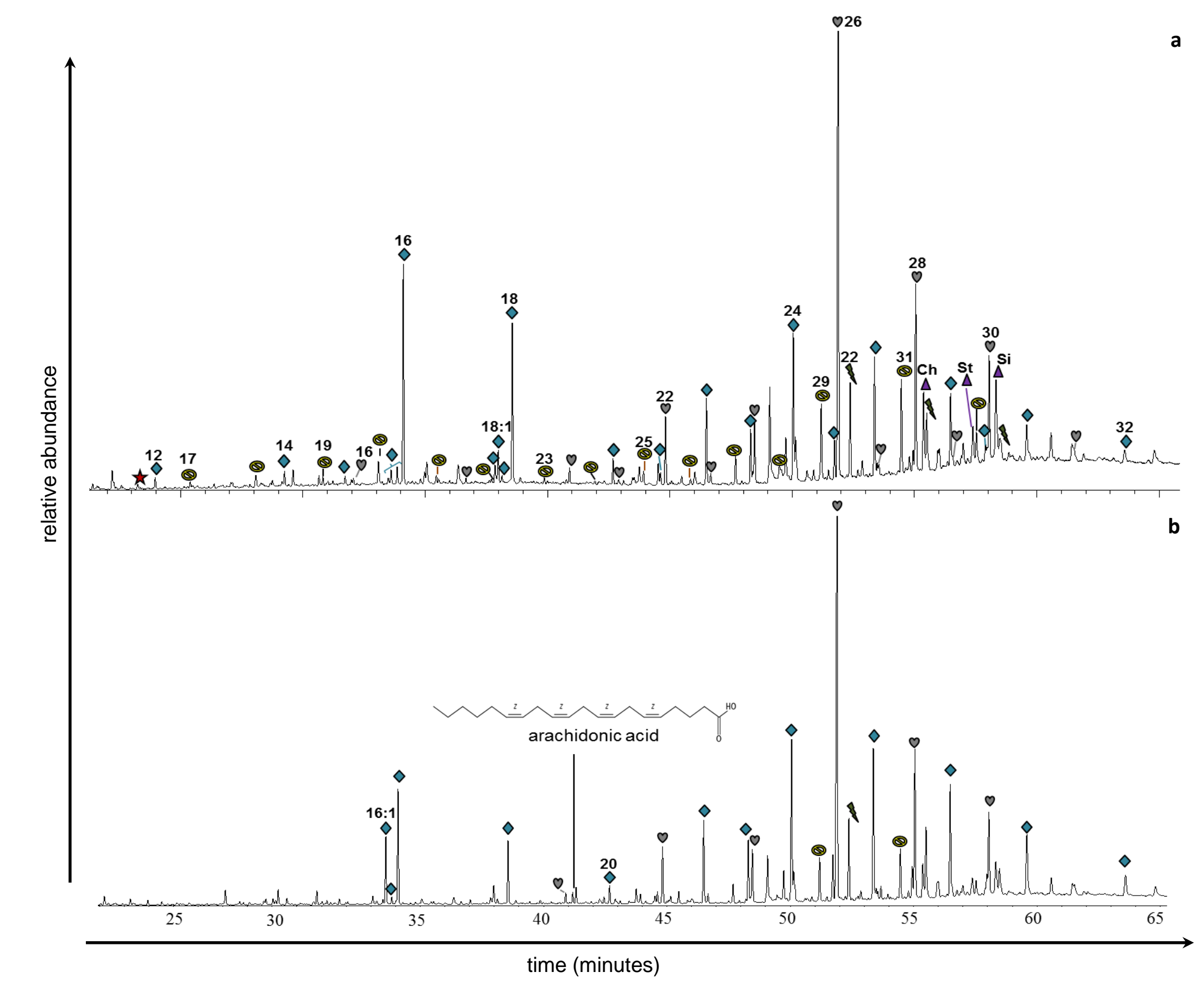


Figure 3
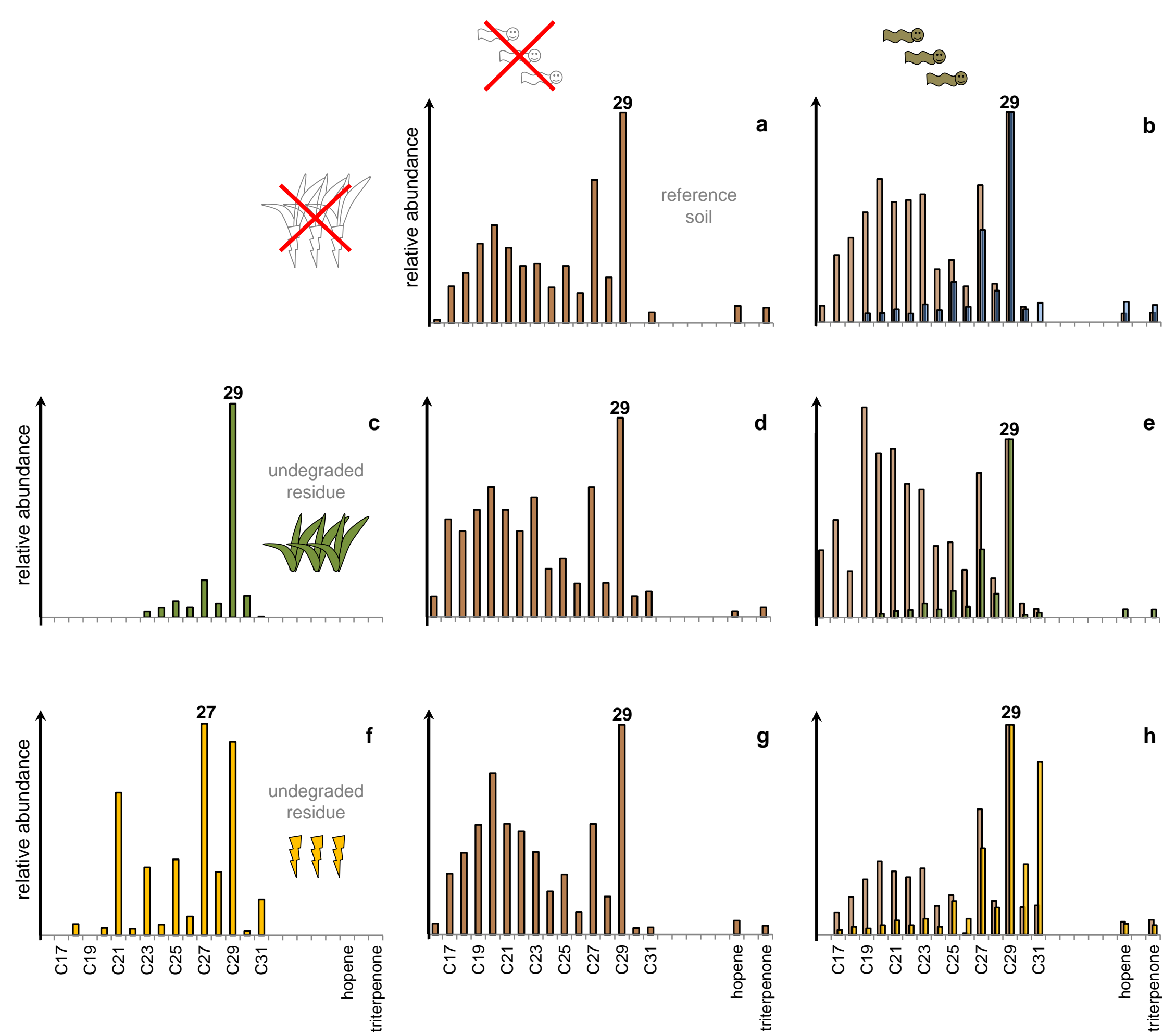
Figure 4

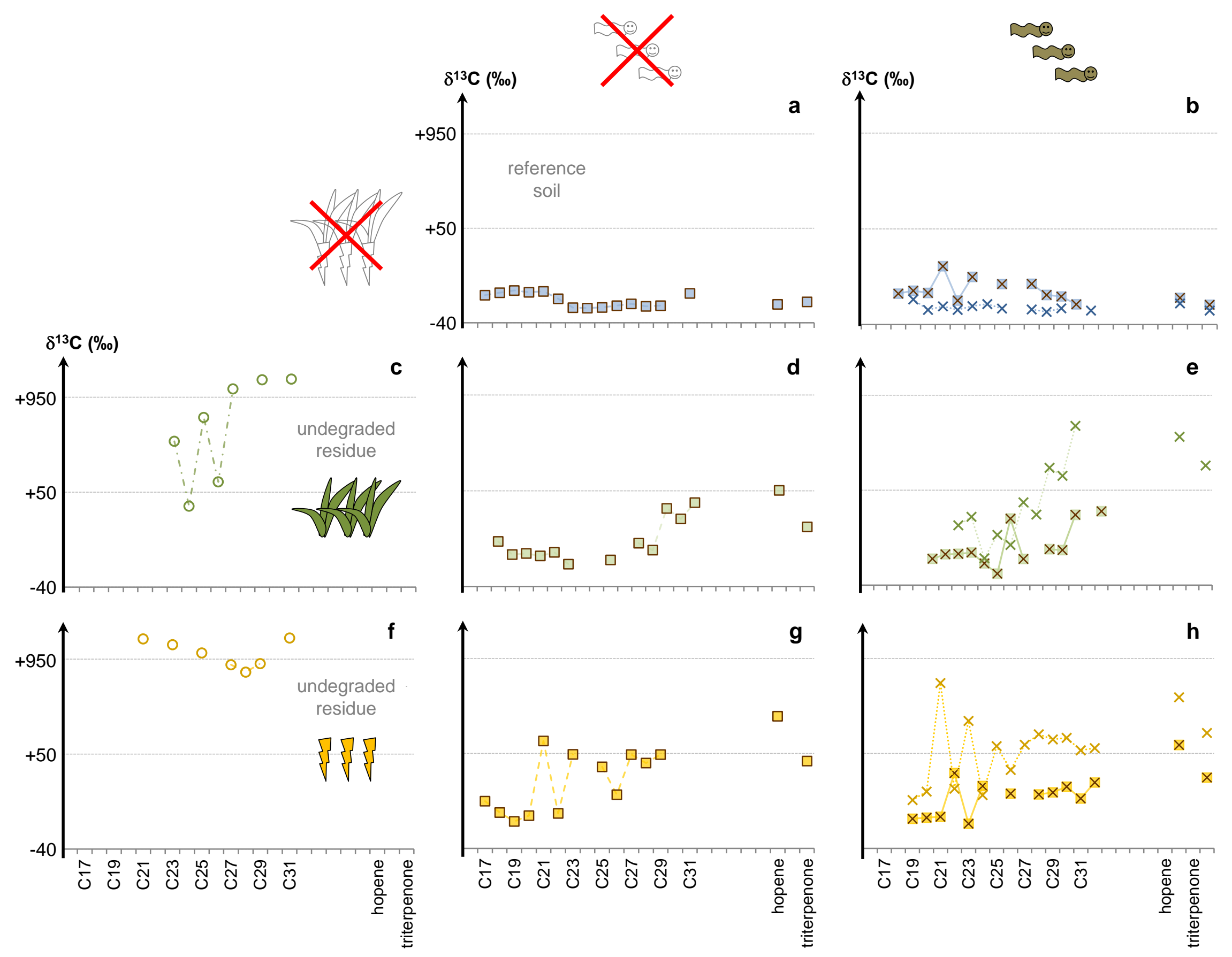


Electronic Supplementary Material 1

Click here to access/download

Electronic Supplementary Material ESM1.pptx 
Electronic Supplementary Material 2

\section{Click here to access/download \\ Electronic Supplementary Material ESM2.xlsx}


Electronic Supplementary Material 3

\section{Click here to access/download \\ Electronic Supplementary Material ESM3.pptx}

